\title{
THE LARVAE OF LYCAENA THEONUS LUCAS FEED ON BUDS AND FLOWERS OF LIIVA BEAN AND CROTALARIA INCANA IN PUERTO RICO
}

\author{
By George N. WoLcotr, Entomologist, \\ Insular Experiment Station, Río Piedras, Puerto Rico
}

The small, greenish, slug-like caterpillars of the little blue butterfly, Lycaena theonus Lucas, are reported by Bruner (1) as feeding on the pods of lima beans in Cuba. These butterflies were extremely abundant at Isabela in 1931-32 in a planting of young casuarina trees close to a field of lima beans, but the larvae were not discovered at the time. In a close examination of a few lima bean plants at Río Piedras, August 2, 1933, two larvae were noted eating the flowers and buds. One transformed to a gray pupa, from which an adult emerged which was determined by Dr. Wm. Schaus, the present being the first published record of this species from Puerto Rico.

Later, when many pods of Crotalaria incana were being collected at Mameyes, several caterpillars were found among the immature pods, possibly feeding upon them, or more probably on the buds and flowers. At Río Piedras, butterflies were observed hovering over the Crotalaria plants, and at times alighting upon them. One female was observed to oviposit, Dec. 28,1933 , on the very top of a flower spray, the egg being light bluish-green in color, turban-shaped like the illustration (Fig. 7) in Holland's "The Butterfly Book," but not so deeply sculptured, and entirely smooth in the depression on top.

\section{BIBLIOGRAPHY}

1. Bruner, s. C. "Informe del Departamento de Entomología y Fitopatología, ejercicio de 1929 a 1930." Estación Experimental Agronómica, Santiago de las Vegas, Cuba, p. 74, fig. 14. Habana, March, 1931. (see p. 25). 